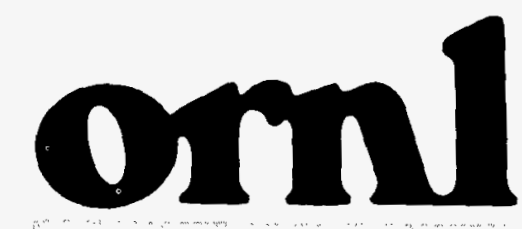

OAK RIDGE NATIONAL LABORATORY

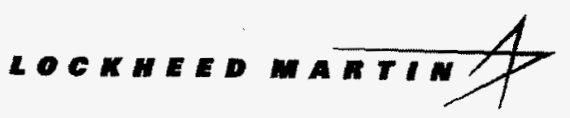

\section{Current and Projected Liquid Low-Level Waste Generation at ORNL}

\author{
RECEIVED \\ APR 081998 \\ OSTI
}

S. M. DePaoli

A. B. Walker

\title{
MASTER
}

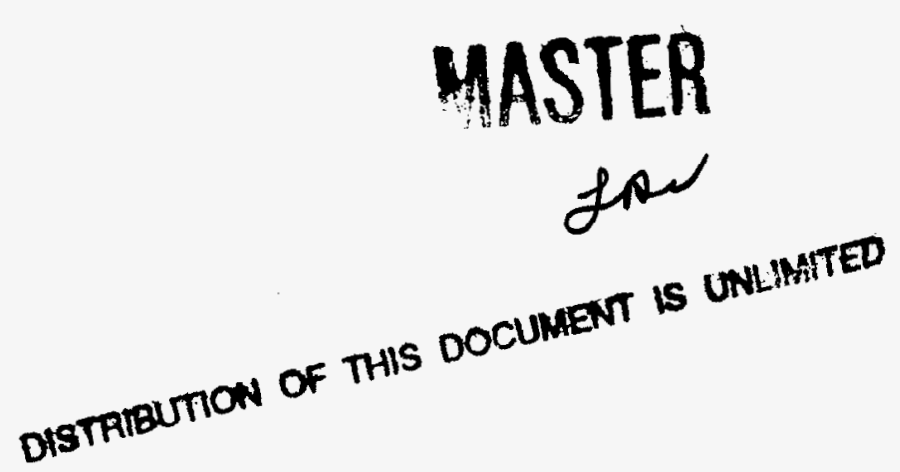

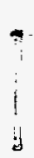


This report has been reproduced directly from the best available copy.

Available to DOE and DOE contractors from the Otfice of Scientific and Technical Information, P.O. Box 62, Oak Ridge, TN 37831; prices available from (615) 576-8401, FTS 626-8401.

Available to the public from the National Technical Information Service, U.S. Department of Commerce, 5285 Port Royal Rd., Springfield, VA 22161.

This report was prepared as an account of work sponsored by an agency of the United States Government. Neither the United States Government nor any agency thereof, nor eny of their employees, makes any warranty, express or implied, or assumes any legal liability or responsibility for the accuracy, completeness, or usefulness of any information, apparatus, product, or process disclosed, or represents that its use would not infringe privately owned rights. Reference herein to any specific commercial product, process. or service by trade name, trademark, manufacturer, or otherwise, does not necessarily constitute or imply its endorsement, recommendation, or favoring by the United States Government or any agency thereof. The views and opinions of authors expressed herein do not necessarily state or reflect those of the United States Government or any agency thereot. 
ORNL/TM-13513

Chemical Technology Division

\section{CURRENT AND PROJECTED \\ LIQUID LOW-LEVEL WASTE GENERATION AT ORNL}

S. M. DePaoli

A. B. Walker

Date Published-March 1998

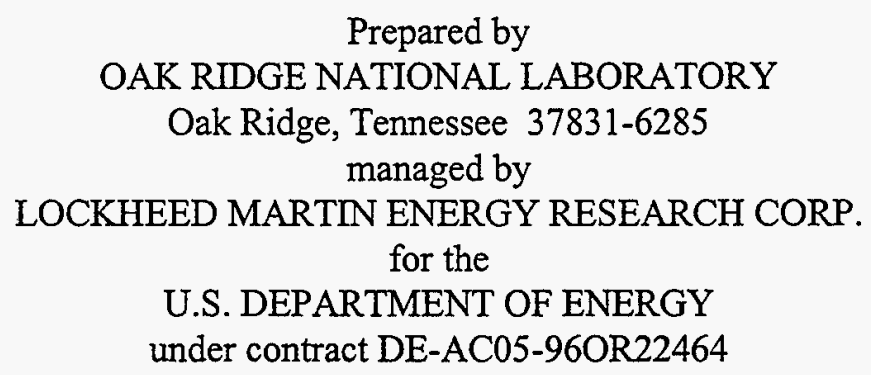


LIST OF TABLES $\ldots \ldots \ldots \ldots \ldots \ldots \ldots \ldots \ldots \ldots \ldots \ldots \ldots \ldots \ldots \ldots$

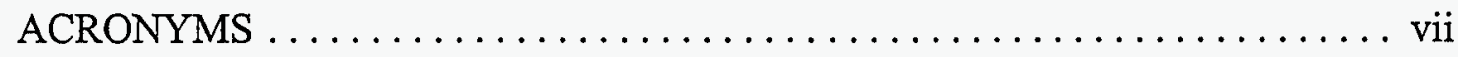

EXECUTIVE SUMMARY $\ldots \ldots \ldots \ldots \ldots \ldots \ldots \ldots \ldots \ldots \ldots \ldots \ldots \ldots \ldots \ldots$

1. INTRODUCTION $\ldots \ldots \ldots \ldots \ldots \ldots \ldots \ldots \ldots \ldots \ldots \ldots \ldots \ldots \ldots \ldots$

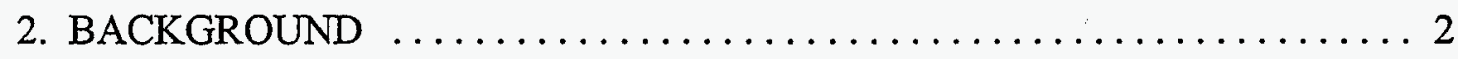

3. GENERATION OF LIQUID LOW-LEVEL WASTE $\ldots \ldots \ldots \ldots \ldots \ldots \ldots 5$

3.1 Generation of Dilute LLLW $\ldots \ldots \ldots \ldots \ldots \ldots \ldots \ldots \ldots \ldots \ldots$

3.1.1 Current Generation of Dilute LLLW $\ldots \ldots \ldots \ldots \ldots \ldots \ldots \ldots$

3.1.2 Projected Future Generation of Dilute LLLW ............ 10

3.2 Characteristics of LLLW . . . . . . . . . . . . . . . . . . . . . 14

3.2.1 Characteristics of Current LLLW $\ldots \ldots \ldots \ldots \ldots \ldots \ldots \ldots \ldots \ldots$

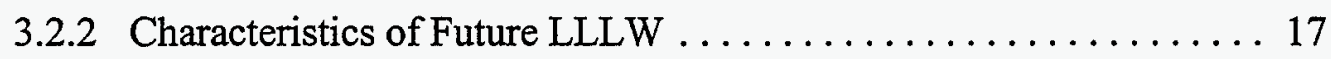

3.3 Generation of LLLW Concentrate $\ldots \ldots \ldots \ldots \ldots \ldots \ldots \ldots \ldots \ldots \ldots \ldots$

3.3.1 Current Generation of LLLWC . . . . . . . . . . . . . . . 18

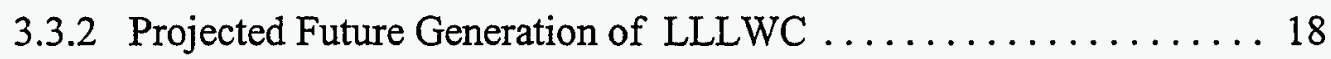

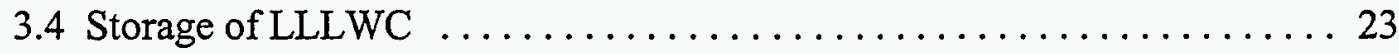

4. SUMMARY AND CONCLUSIONS $\ldots \ldots \ldots \ldots \ldots \ldots \ldots \ldots \ldots \ldots \ldots \ldots$

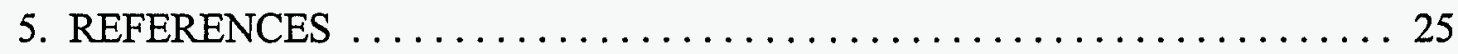




\section{LIST OF TABLES}

Table

Page

1 Generation of dilute liquid low-level waste for the period 1994-1997 . . . . . . . . . . . . . . . . . . . . . . . . . . . . . . . . . . . . . . 7

2 Predicted generation of dilute liquid low-level waste for the

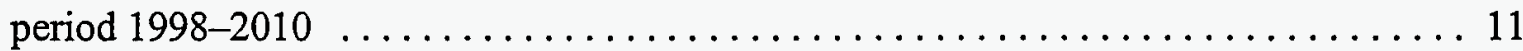

3 Isotopes in liquid low-level waste reported by generators for

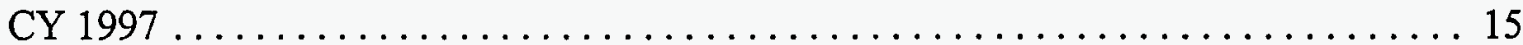

4 Contaminants disposed of via the liquid low-level waste system in 1997 , as reported by generators 16

5 Generation of liquid low-level waste concentrate for the period 1993-1997 19

6 Projected generation of liquid low-level waste concentrate for the period 1998-2010 


\section{ACRONYMS}

$\begin{array}{ll}\text { BSR } & \text { Bulk Shielding Reactor } \\ \text { BV } & \text { Bethel Valley } \\ \text { CY } & \text { calendar year } \\ \text { D\&D } & \text { decontamination and decommissioning } \\ \text { DOE } & \text { U.S. Department of Energy } \\ \text { ERP } & \text { Environmental Restoration Program } \\ \text { EST } & \text { evaporator service tank } \\ \text { FFA } & \text { Federal Facilities Agreement } \\ \text { GAAT } & \text { Gunite and Associated Tanks } \\ \text { HFIR } & \text { High Flux Isotope Reactor } \\ \text { HOG } & \text { hot off-gas } \\ \text { IFDP } & \text { Isotopes Facilities Deactivation Project } \\ \text { ITE } & \text { in-tank evaporation } \\ \text { LITR } & \text { Low-Intensity Test Reactor } \\ \text { LLLW } & \text { liquid low-level waste } \\ \text { LLLWC } & \text { liquid low-level waste concentrate } \\ \text { LLW } & \text { low-level waste } \\ \text { MVST } & \text { Melton Valley Storage Tank } \\ \text { NTF } & \text { North Tank Farm } \\ \text { OGR } & \text { Old Graphite Reactor } \\ \text { OHF } & \text { Old Hydrofracture Tanks } \\ \text { ORNL } & \text { Oak Ridge National Laboratory } \\ \text { ORR } & \text { Oak Ridge Research Reactor } \\ \text { OSR } & \text { Operational Safety Report } \\ \text { OTE } & \text { out-of-tank evaporation } \\ \text { PWTP } & \text { Process Waste Treatment Plant } \\ \text { R\&D } & \text { research and development } \\ \text { RA } & \text { remedial actions } \\ \text { REDC } & \text { Radiochemical Engineering Development Center } \\ \text { SC } & \text { solidification campaign } \\ \text { STF } & \text { South Tank Farm } \\ \text { TRU } & \text { transuranic } \\ \text { VOG } & \text { vessel off-gas } \\ \text { VRF } & \text { volume reduction factor } \\ \text { WAG } & \text { Waste Area Grouping } \\ & \end{array}$




\section{EXECUTIVE SUMMARY}

Liquid low-level waste (LLLW) is generated by various programs and projects throughout Oak Ridge National Laboratory (ORNL). This waste is collected via bottles, trucks, or underground collection tanks. It is then neutralized with sodium hydroxide, reduced in volume at the ORNL LLLW evaporator, and stored as concentrated LLLW in one of twelve storage tanks. Many other tanks (called inactive tanks), which contain historical liquids and sludges generated by past activities, will be remediated; the sludges and associated sluicing and scabbling liquids will then be transferred to the "active" system for treatment and storage. This report presents historical and projected data concerning the volume and the characterization of LLLW, both prior to and after evaporation. Storage space for projected waste generation is also discussed. 


\section{INTRODUCTION}

The Waste Management Operations Group within the Waste Management and Remedial Action Division operates the Oak Ridge National Laboratory (ORNL) liquid low-level waste (LLLW) system, which collects radioactive wastewaters produced by reactor operations, research and development (R\&D) projects, Environmental Restoration Program (ERP) activities, and waste operations. The ongoing effort to develop and implement improved liquid processing systems has the following objectives: (1) to provide facilities for treating all present and future wastewaters generated at ORNL, (2) to meet applicable regulatory requirements, and (3) to improve effluent quality while reducing the volume of secondary waste generated. Efforts began in the mid-1980s to develop a consistent, logical approach for upgrading the low-level waste system to meet these objectives. A strategy was developed for upgrading the LLLW system; R\&D programs and technical assessments were initiated to support these plans, and capital projects were implemented to perform the planned upgrades. This report was prepared to support the LLLW management strategy by summarizing the evaluations of current and future waste characterization/generation data, changes in interagency agreements and regulations, and advances in the R\&D program to treat LLLW. 


\section{BACKGROUND}

LLLW has been generated at ORNL since the inception of laboratory operations in the 1940s. This type of waste is usually collected in underground storage tanks (or, more recently, has been collected in bottles and trucked), neutralized with sodium hydroxide, and then transferred to the central LLLW system, where it is concentrated via evaporation. The liquid LLW concentrate (LLLWC) that is removed as bottoms from the evaporators is transferred to the evaporator service tanks (ESTs) and the Melton Valley Storage Tanks (MVSTs), where it separates into sludge and supernate phases. This waste is stored in the MVSTs until further processing steps render it suitable for disposal.

For 20 years (1964-1984) the LLLWC was stirred into a homogeneous mixture, mixed with grout, and disposed of via underground hydrofracturing. Following the discontinuation of hydrofracture disposal in 1984, LLLWC has been allowed to accumulate in the ESTs and the MVSTs. A line-item project termed the Melton Valley Storage Tank Capacity Increase Project (MVSTCIP) is currently under way to install six new 100,000 gal storage tanks at the Melton Valley site. These tanks are currently scheduled to be operable in late 1998.

In 1987, a planning team was established to develop a strategy for the disposal of the LLLWC stored since the shutdown of the hydrofracture disposal facility. The recommended action plan contained near-, intermediate-, and long-term treatment plans for management of LLLWC at ORNL. ${ }^{1}$ 
The near-term management plan for treatment of LLLWC consisted of three phases: (1) reduction of generated wastes by identifying and evaluating LLLW sources and treatment systems, (2) removal of excess water from the stored waste by in-tank evaporation (ITE) in the MVSTs, and (3) solidification of MVST supernate in a concrete matrix to free storage space in the tanks and to provide operational flexibility of the current LLLW system. The intermediate-term management plan for LLLWC was to process existing MVST transuranic (TRU) waste sludge and the associated supernate for disposal at the Waste Isolation Pilot Plant (WIPP), which is the deep geologic repository that the U.S. Department of Energy (DOE) is establishing as the disposal site for all DOE-generated TRU waste. The long-term management plan recommended the development of a treatment flowsheet that would produce a solid waste form for on-site disposal of newly generated LLLWC and would minimize the production of TRU waste and other solid waste requiring off-site disposal.

Significant accomplishments and changes have occurred since this strategy was developed. The near-term plans outlined above have been completed. The sources of LLLWC have been identified, and source treatment options are being developed for the largest generators of LLLWC. The ITE method was used successfully for a period of almost 3 years (1992-1994), during which a total of approximately $45,000 \mathrm{gal}$ of water was evaporated from the MVSTs. Four solidification campaigns, in which a total of approximately 193,000 gal of supernate was solidified and stored, were successfully completed by the end of 1995 . If the present LLLW generation rates were continued and no other treatment of MVST waste was planned, capacity for about 5 years of LLLWC storage would be available. However, waste generation from remedial activities, 
primarily the emptying of inactive LLLW tanks, is expected to require additional space in the MVSTs, thus decreasing the capacity to fewer than 2 years of available storage. Provided that current schedules are maintained, the Capacity Increase Tanks (CITs) will be available before this time.

With regard to the intermediate plans for treatment of LLLWC, a Request for Proposals (RFP) has been issued by DOE to the private sector for the removal, treatment, and disposal of the sludges and supernates now present in the inactive tanks, the Melton Valley tanks, and the Bethel Valley ESTs. All these wastes will be accumulated over the next several years in the MVSTs, with the exception of the supernates; portions of the supernates will be contained in the new CITs. The RFP requests that this treatment be initiated in 2002.

Funding is not currently available for the development and implementation of long-term onsite treatment of LLLW generated during and after the processing of the legacy waste by the private sector. Thus, newly generated LLLW (waste generated during and after about 2000) will be stored in the CITs for the foreseeable future. Currently, the Radiochemical Engineering Development Center (REDC) is the only facility that generates a TRU waste product, and ongoing studies for the removal and onsite treatment of the transuranic portion of their waste will render the "newly generated" waste non-TRU.

Three previous reports have summarized LLLW generation through $1995 .^{2-4}$ This report will summarize the generation of LLLW since 1995 and will discuss projected generation rates over the decade. Operations to reduce LLLWC over the last few years will be discussed, as will the plans currently being developed to reduce LLLW generation and activity in the near future. 


\section{GENERATION OF LIQUID LOW-LEVEL WASTE}

This document summarizes the status of LLLW generators, along with their waste volumes and characteristics, and analyzes the operation of the current LLLW system. Changes in the generation of dilute LLLW over the past few years have been minimal. Prior to 1994, many changes took place in the use and operation of the LLLW system, including (1) shutdown of the isotope production programs, (2) shutdown of the Oak Ridge Research Reactor (ORR) and Bulk

Shielding Reactor (BSR), and (3) restart of the High Flux Isotope Reactor (HFIR). The Federal Facilities Agreement (FFA) took effect in January 1992, which led to the shutdown of many active LLLW tanks. The generators that had previously used those tanks began bottling or trucking LLLW. Many of those tanks are now collecting only nonprogrammatic waste (filter-pit inleakage, sumps, etc.); some have been filled with grout, and others are ready to be grouted in place. Within the next few years, source treatment of LLLW at the HFIR, source treatment at the REDC, and rerouting of some nonprogrammatic waste streams will have a significant impact on operations of the LLLW system. Conversely, the shutdown of many facilities is predicted to temporarily generate large volumes of LLLW in the future, as will the consolidation of inactive tank sludges and supernates in the MVSTs.

Data to support the analysis of the LLLW (dilute and concentrate) generated have been obtained over the past 9 years through generator surveys. These surveys have provided information on (1) the programs and activities that generate LLLW, (2) estimates of the volumes of dilute LLLW, (3) radioactivity of the waste, and (4) solids contents of the waste (caustic, cleaners, 
acids, bases, etc.). This information has been used to predict dilute and concentrated waste generation rates for the generators and to determine their needs with regard to concentrate storage volumes. Section 3 summarizes the information received during CY 1997, as well as the forecasted changes as currently envisioned.

\subsection{GENERATION OF DILUTE LLLW}

\subsubsection{Current Generation of Dilute LLLW}

For purposes of this report, LLLW that will be volume reduced by evaporation in the Bethel Valley evaporators is termed dilute LLLW. Table 1 presents the historical generation of dilute LLLW from 1994 through 1997 (based on collection rates and the 1997 generator surveys). Generator LLLW (as opposed to nonspecific source generation, e.g., inleakage and sump accumulation) volumes have not changed significantly during the past 4 years. Nonspecific source generation fluctuates with rainfall; however, this volume does not significantly add to the LLLW concentrate volume and, therefore, is not a concern. A discussion of LLLW collection tanks and associated generators with their expected generation for the current year is provided below.

WC-10 - (Building 3047). An estimated $80 \mathrm{gal} /$ month (1000 gal/year) of dilute LLLW was generated in 1997 as a result of the decontamination of hot cells after radioisotope processing. Other isotope facilities are still actively connected to tank WC-10, but they are not expected to undergo significant amounts of cleanup or decontamination until the Isotopes Facilities Deactivation Project (IFDP) commences. 
Table 1. Generation of dilute liquid low-level waste for the period 1994-1997

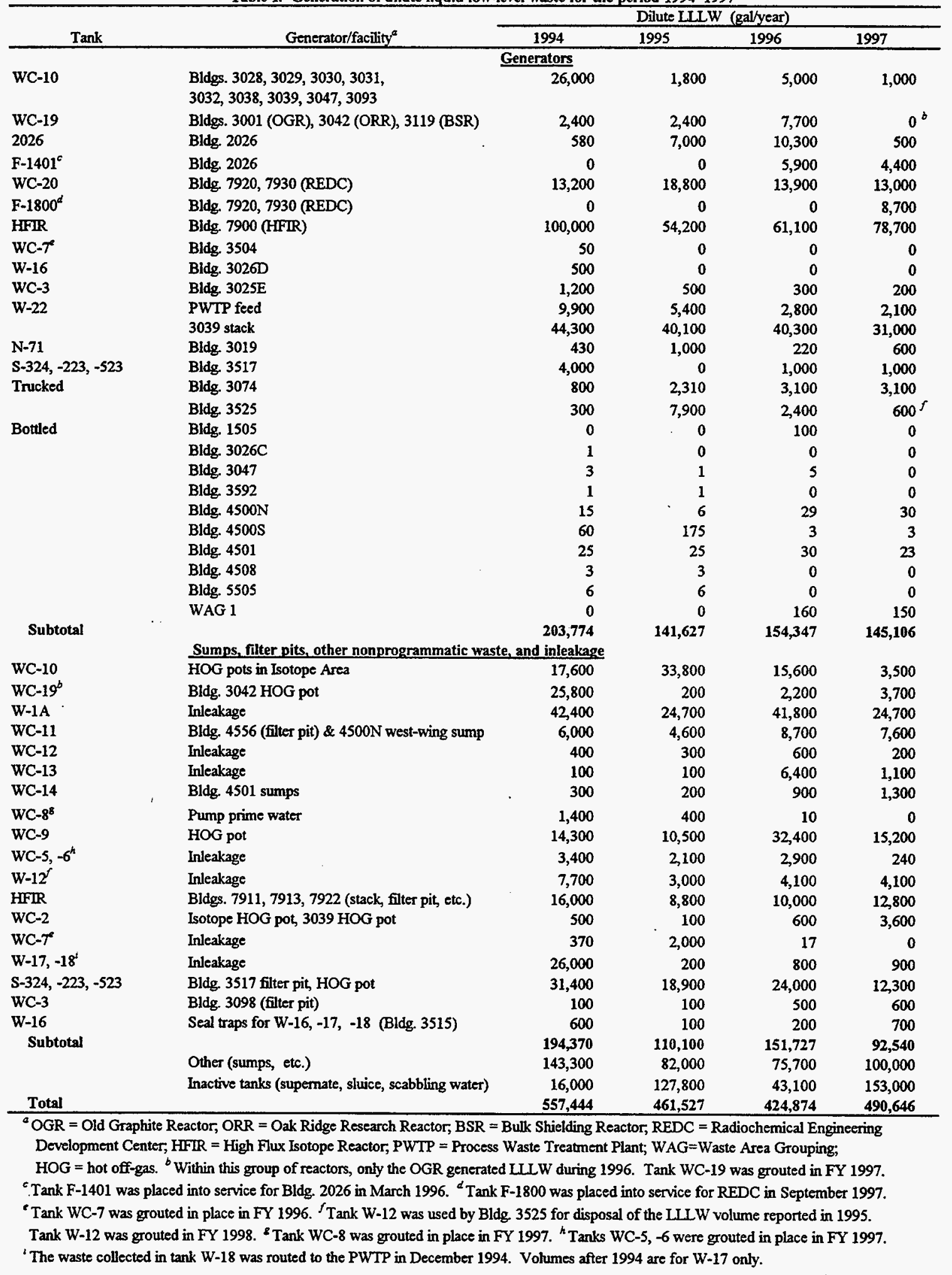


F-1401 - (Building 2026). Tank F-1401 was placed in service for Building 2026 in March 1996. Since that time, generator estimates for this facility have been slightly lower than actual collections. The generation for 1997 was approximately $370 \mathrm{gal} / \mathrm{month}$ (4400 gal/year). Cleanup of Tank 2026, the tank that previously collected Building 2026 LLLW, was completed in early 1997; and collections since that time have approached zero.

F-1800 - (REDC). Tank F-1800 was placed into service for REDC in September 1997 replacing tank WC-20 in report summaries. Tank decontamination activities associated with switching to the new LLLW collection tank, rather than actual processing, accounted for the increase in LLLW volumes observed in 1997. REDC processing activities generate approximately 15,000 gal of dilute LLLW per year.

HFIR - HFIR generation has remained approximately the same for the past four years (all operating years). The 1997 generator estimate of 100,000 gal appears to be slightly conservative (based on the actual generation), and is better estimated to be approximately 80,000 gal for the year. A system to produce only solid LLW will eliminate the generation of LLLW from HFIR. W-16 - (Building 3026D). Collections in tank W-16 increased significantly during the last quarter of 1997 , to approximately $190 \mathrm{gal} / \mathrm{month}$ as compared with $10 \mathrm{gal} / \mathrm{month}$ for the first nine months of 1997. This increase is assumed to be due to decontamination activities; however, the source of the increase has not yet been confirmed.

WC-3 - (Building 3025E). The 1997 generator estimate for Building 3025E is 200 gal. This estimate is slightly lower than that of previous years and appears to be underestimated based 
on actual generation. Building 3098, the filter facility for the BSR and the Low-Intensity Test Reactor, also discharges an estimated 100 gal to this tank annually.

WC-2 - (Buildings 3028 and 3038AHF). Collections in tank WC-2 have increased significantly in 1997, to approximately $300 \mathrm{gal} /$ month as compared with $50 \mathrm{gal} / \mathrm{month}$ from 1994 through 1996. This increase is assumed to be the result of hot cell decontamination; however, the source of the increase has not yet been confirmed.

W-17 - (Building 3026C). Tank W-17 volumes have increased in 1997, presumably due to decontamination activities; however the source of the increase has not yet been confirmed.

N-71 - (Building 3019). Building 3019 research and decontamination activities generate LLLW that is collected in tank N-71 prior to its transfer to W-22 via valve box 1B. Transfers typically occur once or twice per year. One transfer of about 600 gal occurred in 1997.

S-324, -223, -523 - (Building 3517). Currently, this facility is doing minimal cell washings to contain radioactivity. Approximately 1000 gal/year of dilute LLLW is estimated to be generated by this procedure. The remainder of the volume collected in tanks S-324, -223 , and -523 is reportedly due to rainfall inleakage.

W-12 - (Building 3525). Building 3525 was allowed to use tank W-12 temporarily in 1995 to perform major decontamination work. Since that time, Building 3525 has trucked waste to the LLLW evaporators (see the discussion under Trucked waste), and waste collected in Tank W-12 resulted from inleakage. Tank W-12 was stabilized in place in December 1997.

Trucked waste - (Buildings 3074, 3525, and 7830). The Manipulator Repair Facility (Building 3074) estimated a total generation of 3600 gal for CY 1997. This estimate is on target 
with the actual generation of $3100 \mathrm{gal}$ and is consistent with the generation rate for 1996 . Building 3525 projected a trucked volume of 600 gal for CY 1997 . Waste is also trucked from sumps at Building 7830 , an inactive facility, as necessary.

Bottled waste - (Chemical and Analytical Sciences Division, Chemical Technology Division, Life Sciences Division, Office of Environmental Compliance and Documentation). A total of 206 gal of dilute LLLW is estimated to be bottled by these divisions during CY 1997.

Inactive tanks - (W-1, W-3, W-4, W-8, W-9, W-10, Tank 7562). Approximately 153,000 gal of dilute LLLW was transferred from inactive tanks to the LLLW system in CY 1997.

The major dilute LLLW generators for 1997 are as follows: nonprogrammatic/inleakage (39\%), inactive tanks (31\%), HFIR (16\%), the 3039 stack (6\%), and the REDC (4\%); all others account for the remaining 4\% of dilute LLLW generation for 1997.

\subsubsection{Projected Future Generation of Dilute LLLW}

Several changes are expected in the generation of dilute LLLW over the next 13 years. Predicted generation rates are listed in Table 2. Included are LLLW generation rates for decontamination and decommissioning (D\&D) activities by the Surplus Facilities Program, as well as remedial actions $(\mathrm{RA})$ that primarily consider the cleanup and remediation of waste area grouping sites by ERP. In each case, the LLLW to be generated is the result of decontamination activities. The transfer of inactive tank supernates will be a major source of dilute LLLW during 
Table 2. Predicted generation of dilute liquid low-level waste for the period 1998-2010

\begin{tabular}{|c|c|c|c|c|c|c|c|c|c|c|c|c|c|}
\hline \multirow[b]{2}{*}{ Tank (facility) ${ }^{a}$} & \multicolumn{13}{|c|}{ Dilute LLLW (gal/year) } \\
\hline & 1998 & 1999 & 2000 & 2001 & 2002 & 2003 & 2004 & 2005 & 2006 & 2007 & 2008 & 2009 & 2010 \\
\hline \multicolumn{14}{|c|}{ Generators } \\
\hline WC-2, -10 (Isotope Area) & 68,000 & 68,000 & 68,000 & 2,000 & 2,000 & 2,000 & 2,000 & 2,000 & 2,000 & 2,000 & 2,000 & 2,000 & 2,000 \\
\hline 2026 (Bldg. 2026) & 2,000 & 2,000 & 2,000 & 2,000 & 2,000 & 2,000 & 2,000 & 2,000 & 2,000 & 2,000 & 2,000 & 2,000 & 2,000 \\
\hline WC-20 (REDC) & 15,000 & 15,000 & 15,000 & 15,000 & 15,000 & 15,000 & 15,000 & 15,000 & 15,000 & 15,000 & 15,000 & 15,000 & 15,000 \\
\hline W-16 (Bidg. 3026D) & 37,000 & 37,000 & 0 & 0 & 0 & 0 & 0 & 0 & 0 & $\mathbf{0}$ & 0 & 0 & 0 \\
\hline WC-3 (Bldg. 3025) & 200 & 200 & 200 & 200 & 200 & 200 & 200 & 200 & 200 & 200 & 200 & 200 & 200 \\
\hline W-22 (3039 Stack) & 44,000 & 44,000 & 44,000 & 44,000 & 44,000 & 44,000 & 44,000 & 44,000 & 44,000 & 44,000 & 44,000 & 44,000 & 44,000 \\
\hline N-71 (Bldg. 3019) & 250 & 250 & 250 & 250 & 250 & 250 & 250 & 250 & 250 & 250 & 250 & 250 & 250 \\
\hline S-523 (Bldg. 3517) & 93,500 & 93,500 & 93,500 & 400 & 400 & 400 & 400 & 400 & 400 & 400 & 400 & 400 & 400 \\
\hline Trucked (Bldg. 3074) & 3,600 & 3,600 & 3,600 & 3,600 & 3,600 & 3,600 & 3,600 & 3,600 & 3,600 & 3,600 & 3,600 & 3,600 & 3,600 \\
\hline (Bldg. 3525) & 600 & 600 & 600 & 600 & 600 & 600 & 600 & 600 & 600 & 600 & 600 & 600 & 600 \\
\hline Bottled (various bldgs.) & 200 & 200 & 200 & 200 & 200 & 200 & 200 & 200 & 200 & 200 & 200 & 200 & 200 \\
\hline Spallation Neutron Source & $\mathbf{0}$ & 0 & $\mathbf{0}$ & $\mathbf{0}$ & $\mathbf{0}$ & 0 & 800 & 800 & 800 & 800 & 800 & 800 & 800 \\
\hline Subtotal & 264,350 & 264,350 & 227,350 & 68,250 & 68,250 & 68,250 & 69,050 & 69,050 & 69,050 & 69,050 & 69,050 & 69,050 & 69,050 \\
\hline \multicolumn{14}{|c|}{ Others } \\
\hline Nonprogrammatic waste $^{b}$ & 250,000 & 250,000 & 250,000 & 250,000 & 250,000 & 250,000 & 250,000 & 250,000 & 250,000 & 250,000 & 250,000 & 250,000 & 250,000 \\
\hline Inactive-tanks supernate, etc. ${ }^{c}$ & 95,000 & 335,000 & 414,000 & 0 & 0 & 0 & 0 & 0 & $\mathbf{0}$ & 0 & $\mathbf{0}$ & 0 & 0 \\
\hline EM-40 activities ${ }^{d}$ & 100 & 280,400 & 1,400 & 1,500 & 2,800 & 2,400 & 200 & $\mathbf{0}$ & 500 & 3,400 & 12,200 & 20,400 & 9,800 \\
\hline Subtotal & 345,100 & 865,400 & 665,400 & 251,500 & 252,800 & 252,400 & 250,200 & 250,000 & 250,500 & 253,400 & 262,200 & 270,400 & 259,800 \\
\hline Total & 609,450 & $1,129,750$ & 892,750 & 319,750 & 321,050 & 320,650 & 319,250 & 319,050 & 319,550 & 322,450 & $\mathbf{3 3 1 , 2 5 0}$ & $\mathbf{3 3 9 , 4 5 0}$ & $\mathbf{3 2 8 , 8 5 0}$ \\
\hline
\end{tabular}

${ }^{b}$ Nonprogrammatic waste refers to inleakage, collection in hot off-gas pots, stacks, etc., throughout the active LLLW system.

${ }^{c}$ The inactive tank supernate volume reported here includes all dilute supernate, process sluice water, and scabbling process water volume estimates.

${ }^{d}$ This includes Remedial Action activities and facility D\&D activities. 
the next decade, as will decontamination of the isotope facilities. The following paragraphs summarize changes in LLLW generation expected by the current generators.

Tank WC-10 is serving only to maintain and, eventually, to decontaminate the isotope facilities. The shutdown of these facilities is dependent on the availability of funding for the IFDP. ${ }^{5}$ Currently, such funding is not expected before 1998; following its receipt, shutdown is expected to require approximately 4 years to complete for all facilities. The disposition of WC-2 and WC-10 during this period is uncertain. The volumes to be expected were taken from the Work Plan for the Isotopes Facilities Deactivation Project at Oak Ridge National Laboratory (see Table 2). ${ }^{5}$ Building 3517 , which is also an isotope facility, will be decontaminated and decommissioned on the schedule outlined in the IFDP.

The LLLW from HFIR will possibly be eliminated by 1998 . Resins in the ion-exchange columns (used to demineralize and reduce the radioactivity in the pool waters) are presently regenerated, resulting in a large volume of LLLW. In the near future, they will be replaced with a resin that will be disposed of as a solid waste. Inleakage to the HFIR, T-1, and T-2 tanks will continue to be treated by Waste Operations in Bethel Valley.

Building 2026, which is operating on a full, normal schedule now, is using a newly installed, doubly contained tank (F-1401). No changes are expected in dilute LLLW generation at the facility within the next several years.

REDC is researching various techniques for the removal of TRU elements from its waste stream, although the volume is not expected to decrease markedly with this further treatment step. Significant strides in volume reduction have occurred in the previous few years at REDC 
following conversion of their off-gas scrubber solution to a sodium hydroxide form. (Previously, a more concentrated solution of potassium hydroxide was used.)

Building $3026 \mathrm{D}$, which is part of the IFDP, is scheduled to be decontaminated/

decommissioned in the same time frame as the other isotope facilities. ${ }^{5}$ Liquid waste generated during the past few years at this building has been the result of cleanup and decontamination activities. The final cleanup and decontamination of the facility are dependent on budget concerns and availability and, therefore, are subject to change, depending on the procurement of these funds. The disposition of tank W-16 during this period is unknown.

Forecasts for LLLW generation by EM-40 projects (D\&D projects and RA activities) at ORNL have been incorporated in the projections in this report for planning purposes. LLLW projections for this program have significantly decreased over those made in previous years. The LLLW generated through these programs will be primarily decontamination liquids. A large volume reduction factor (VRF) was applied to these dilute volumes when predicting concentrate volumes.

A new facility, the National Spallation Neutron Source, is currently being designed. This facility, which is scheduled to begin operation in 2004 , is predicted to have a dilute LLLW generation rate of $800 \mathrm{gal} / \mathrm{month}^{6}$

For projection purposes, the generation rates for the remainder of the facilities have been assumed to remain constant for the 1998-2010 time frame. However, these estimates are certain to change as time progresses. 


\subsection{CHARACTERISTICS OF LLLW}

\subsubsection{Characteristics of Current LLLW}

Generators are also asked to report on the radioactive contents of the liquid waste in the LLLW surveys. Table 3 summarizes the current findings on radioactive species being disposed of through the LLLW system, as reported in the surveys for CY 1997. The curie quantities given in the table are estimates; actual sample analyses have not been made. REDC is the source of the majority of the radioactivity in the currently generated LLLW, and this area will continue to contribute significantly to the total activity of the waste. In addition, the estimated volume to be sent to the LLLW system by the inactive tanks will also contribute to the activity of the waste (See Table 3).

Other contaminants (e.g., cleaners, acids, caustics, and salts used and disposed of by the facility) determine the volume of LLLWC generated. Most facilities use nitric acid, sodium hydroxide, and commercial cleansers (e.g., Ajax ${ }^{\mathrm{TM}}$ and Mr. Clean ${ }^{\mathrm{TM}}$ ) when decontaminating and washing hot cells. In addition, the caustic that is added to many of the tanks before the contents are jetted or pumped to the central LLLW system for evaporation also increases the volume of concentrate produced. The amounts of such agents used by the facility (or added to the tank receiving effluent from the facility) determine the VRF that will be achieved when the waste is processed through the LLLW evaporator. This VRF is used in calculating the volume of LLLWC generated by the facility. Table 4 lists the major contaminants in the LLLW generated during CY 1997, as estimated in the LLLW surveys. 
Table 3. Isotopes in liquid low-level waste reported by generators for CY $1997^{\circ}$

\begin{tabular}{|c|c|c|c|}
\hline Isotope & Facility & $\begin{array}{c}\text { Quantity } \\
\text { for each facility } \\
\text { (Ci/year) }\end{array}$ & $\begin{array}{l}\text { Total quantity } \\
\text { of isotope } \\
\text { (Ci/year) }\end{array}$ \\
\hline H-3 & $\begin{array}{l}\text { Bldg. } 7920 \\
\text { Inactive tanks } \\
\text { Others }\end{array}$ & $\begin{array}{r}1.0 \mathrm{E}+01 \\
1.0 \mathrm{E}-03 \\
<1.0 \mathrm{E}-03\end{array}$ & $1.0 \mathrm{E}+01$ \\
\hline$c-14$ & BIdg. $4500 \mathrm{~N}$ & $1.0 \mathrm{E}-03$ & $1.0 \mathrm{E}-03$ \\
\hline Cr-51 & HFIR & $2.1 \mathrm{E}-03$ & 2.1E-03 \\
\hline $\mathrm{Co}-60$ & $\begin{array}{l}\text { Bldg. } 3047 \\
\text { Inactive tanks } \\
\text { Bldg. } 3025 \mathrm{E} \\
\text { Bldg. } 3525 \\
\text { Bldg. } 4501 / 4505 \\
\text { Bldg. } 3092 \\
\text { Others }\end{array}$ & $\begin{array}{r}1.7 \mathrm{E}-01 \\
9.8 \mathrm{E}-02 \\
4.0 \mathrm{E}-03 \\
3.6 \mathrm{E}-03 \\
3.0 \mathrm{E}-03 \\
1.1 \mathrm{E}-03 \\
<1.0 \mathrm{E}-03\end{array}$ & $2.8 \mathrm{E}-01$ \\
\hline $2 n-65$ & $\begin{array}{l}\text { Bldg. } 4500 \text { S } \\
\text { Other }\end{array}$ & $\begin{array}{r}1.0 \mathrm{E}-03 \\
<1.0 \mathrm{E}-03\end{array}$ & $1.0 \mathrm{E}-03$ \\
\hline St-85 & $\begin{array}{l}\text { Bldg. } 4501 / 4505 \\
\text { Bldg. } 4500 \mathrm{~N} \\
\text { Others }\end{array}$ & $\begin{array}{r}6.0 \mathrm{E}-03 \\
5.0 \mathrm{E}-03 \\
<1.0 \mathrm{E}-03\end{array}$ & $1.1 \mathrm{E}-02$ \\
\hline Sr-90 & $\begin{array}{l}\text { Bldg. } 7920 \\
\text { Inactive tanks } \\
\text { Bldg. } 3047 \\
\text { Bldg. } 3544 \\
\text { Bldg. } 4501 / 4505 \\
\text { Bldg. } 3517 \\
\text { Others }\end{array}$ & $\begin{array}{r}7.0 \mathrm{E}+02 \\
7.2 \mathrm{E}+00 \\
1.8 \mathrm{E}+00 \\
8.5 \mathrm{E}-01 \\
3.0 \mathrm{E}-03 \\
1.1 \mathrm{E}-03 \\
<1.0 \mathrm{E}-03\end{array}$ & $7.1 E+02$ \\
\hline Tc-99 & $\begin{array}{l}\text { Bldg. } 4501 / 4505 \\
\text { Bldg. } 45005\end{array}$ & $\begin{array}{l}3.0 \mathrm{E}-03 \\
1.7 \mathrm{E}-03\end{array}$ & 4.7E-03 \\
\hline Cd-109 & $\begin{array}{l}\text { Bldg } 3092 \\
\text { Others }\end{array}$ & $\begin{array}{r}1.9 \mathrm{E}-03 \\
<1.0 \mathrm{E}-03\end{array}$ & $1.9 \mathrm{E}-03$ \\
\hline I-125 & Bldg. 4501 & $5.0 \mathrm{E}-03$ & $5.0 \mathrm{E}-03$ \\
\hline I-13I & Blds. 4501 & $5.0 \mathrm{E}-03$ & $5.0 \mathrm{E}-03$ \\
\hline Cs-134 & $\begin{array}{l}\text { Bldg. } 3525 \\
\text { Others }\end{array}$ & $\begin{array}{r}2.1 \mathrm{E}-03 \\
<1.0 \mathrm{E}-03\end{array}$ & 2.1E-03 \\
\hline $\mathrm{Cs}-137$ & $\begin{array}{l}\text { Bldg. } 7920 \\
\text { Inactive tanks } \\
\text { Bldg. } 3525 \\
\text { Bldg. } 3544 \\
\text { Bldg. } 3074 \\
\text { Bldg. } 4501 / 4505 \\
\text { Bldg. } 4500 \mathrm{~N} \\
\text { Bldg. } 3047 \\
\text { Bldg. } 3092 \\
\text { Othens }\end{array}$ & $\begin{array}{r}2.5 \mathrm{E}+03 \\
6.1 \mathrm{E}+02 \\
1.2 \mathrm{E}+00 \\
1.2 \mathrm{E}-02 \\
7.2 \mathrm{E}-03 \\
6.0 \mathrm{E}-03 \\
5.0 \mathrm{E}-03 \\
1.4 \mathrm{E}-03 \\
1.4 \mathrm{E}-03 \\
<1.0 \mathrm{E}-03\end{array}$ & $3.1 \mathrm{E}+03$ \\
\hline La-140 & Bldg 3047 & $3.5 E+01$ & $3.5 \mathrm{E}+01$ \\
\hline$E u-152,-154,-155$ & $\begin{array}{l}\text { Bldg. } 7920 \\
\text { Bldg. } 3047 \\
\text { Bldg. } 3525 \\
\text { Bldg. } 7900 \\
\text { Others }\end{array}$ & $\begin{array}{r}1.0 \mathrm{E}+02 \\
1.2 \mathrm{E}+00 \\
1.9 \mathrm{E}-02 \\
1.4 \mathrm{E}-03 \\
<1.0 \mathrm{E}-03\end{array}$ & $1.0 \mathrm{E}+02$ \\
\hline W-188 & Bldg. 4501 & $5.0 \mathrm{E}-03$ & $5.0 E-03$ \\
\hline U-233 & $\begin{array}{l}\text { Bldg. } 3019 \\
\text { Inactive tanks }\end{array}$ & $\begin{array}{l}9.6 \mathrm{E}-02 \\
4.5 \mathrm{E}-02\end{array}$ & $1.4 E-01$ \\
\hline U-238 & $\begin{array}{l}\text { Inactive tanks } \\
\text { Bidg. } 3019 \\
\text { Others }\end{array}$ & $\begin{array}{r}8.0 \mathrm{E}-03 \\
7.0 \mathrm{E}-03 \\
<1.0 \mathrm{E}-03\end{array}$ & $1.5 \mathrm{E}-02$ \\
\hline $\begin{array}{l}\text { Pu-238, }-239,-240,-241 \text {, } \\
-242\end{array}$ & $\begin{array}{l}\text { Bldg. } 7920 \\
\text { Others }\end{array}$ & $\begin{array}{r}1.5 \mathrm{E}+\infty \\
<1.0 \mathrm{E}-03\end{array}$ & $1.5 E+00$ \\
\hline Am-241, $-242,-243$ & Bldg. 7920 & $6.0 \mathrm{E}-0 \mathrm{I}$ & $6.0 \mathrm{E}-01$ \\
\hline $\begin{array}{l}\mathrm{Cm}-242,-244,-245,-246, \\
-247,-248\end{array}$ & Bldg 7920 & $4.0 \mathrm{E}+01$ & $4.0 \mathrm{E}+01$ \\
\hline$C f-250,-252$ & Bldg 7920 & $3.2 E-01$ & $3.2 \mathrm{E}-01$ \\
\hline $\begin{array}{l}\text { Mixed fission } \\
\text { products (MFP) }\end{array}$ & Bidg. 7920 & $3.2 E+03$ & $3.2 E+03$ \\
\hline Total & & & $7.2 \mathrm{E}+03$ \\
\hline
\end{tabular}


Table 4. Contaminants disposed of via the liquid low-level waste system in 1997 , as reported by generators

\begin{tabular}{|c|c|c|c|c|c|c|c|}
\hline \multirow[b]{2}{*}{ Contaminant } & \multirow[b]{2}{*}{ Facility } & \multicolumn{2}{|c|}{ Quantity } & \multirow[b]{2}{*}{ Contaminant } & \multirow[b]{2}{*}{ Facility } & \multicolumn{2}{|c|}{ Quantity } \\
\hline & & (g/year) & (Lyear) & & & (g/year) & (L/ycar) \\
\hline Adogen-364 & Bldg. 7920 & & $2.5 \mathrm{E}+01$ & Nitrate & Inactive tanks & $2.3 \mathrm{E}+06$ & \\
\hline Aluminum & Inactive tanks & $1.2 E+03$ & & & Bldg. 4501/450s & $2.0 E+04$ & \\
\hline Arsenic & Inactive tanks & $2.7 \mathrm{E}+00$ & & Nitric acid & Bldg. 2026 & & $9.0 \mathrm{E}+02$ \\
\hline Barium & Inactive tanks & $6.5 \mathrm{E}+01$ & & & Bldg. 3019 & $<6.3 \mathrm{E}+02$ & \\
\hline \multirow[t]{2}{*}{ Boron } & Inactive tanks & $3.3 E+02$ & & & Bldg. 3074 & & $6.0 \mathrm{E}+01$ \\
\hline & Bldg. 4501/4505 & 4.5E-02 & & & Bldg. $3544(3 \mathrm{~N})^{a}$ & & $1.5 \mathrm{E}+04$ \\
\hline Bromine & Bldg. $4501 / 4505$ & $2.0 \mathrm{E}+01$ & & & Bldg. $4500 \mathrm{~N}$ & $2.0 E+01$ & \\
\hline Cadmium & Inactive tanks & $4.2 \mathrm{E}+00$ & & & Bldg. $4500 \mathrm{~S}$ & $1.0 \mathrm{E}+02$ & \\
\hline Calcium & Inactive tanks & $2.4 \mathrm{E}+04$ & & & Bldg. $7900(5 \%)$ & & $7.6 \mathrm{E}+03$ \\
\hline Calcium carbonate & Bldg. $4500 \mathrm{~N}$ & $4.9 \mathrm{E}-01$ & & Petroleum naphtha & Bldg. 7920 & & $2.5 E+02$ \\
\hline Calcium nitrate & Bldg. $4500 \mathrm{~N}$ & $4.0 \mathrm{E}-02$ & & Phosphate & Inactive tanks & $2.4 \mathrm{E}+05$ & \\
\hline \multirow[t]{2}{*}{ Chloride } & Inactive tanks & $1.9 \mathrm{E}+05$ & & Potassium & Inactive tanks & $5.3 \mathrm{E}+05$ & \\
\hline & Bldg. 4501/4505 & $2.0 \mathrm{E}+02$ & & & Bldg. 4501/4505 & $7.0 \mathrm{E}+02$ & \\
\hline \multirow[t]{2}{*}{ Chromium } & Inactive tanks & $5.2 \mathrm{E}+03$ & & Selenium & Inactive tanks & $2.6 \mathrm{E}+00$ & \\
\hline & Bldg. 4501/4505 & $1.5 \mathrm{E}-01$ & & Silicon & Inactive tanks & $7.7 \mathrm{E}+02$ & \\
\hline CMPO & Bldg. 7920 & $2.3 \mathrm{E}+03$ & & & Bldg. $4501 / 4505$ & $1.8 \mathrm{E}+00$ & \\
\hline Cobalt & Inactive tanks & $9.4 \mathrm{E}+01$ & & Silver & Inactive lanks & $1.8 \mathrm{E}+02$ & \\
\hline Copper & Inactive tanks & $2.5 \mathrm{E}+02$ & & Sodium & Inactive tanks & $2.7 \mathrm{E}+06$ & \\
\hline \multirow[t]{5}{*}{ Detergents (Mr. Clean, Ajax, tri chem, etc.) } & Bldg. 2026 & $9.1 \mathrm{E}+04$ & & & Bldg. 4501/450S & $7.5 \mathrm{E}+03$ & \\
\hline & Bldg. 3047 & & $1.9 \mathrm{E}+01$ & Sodium aluminate & Bldg. 7920 & $3.3 \mathrm{E}+04$ & \\
\hline & Bldg. 3074 & & $2.6 \mathrm{E}+02$ & Sodium carbonate & Bldg. 7920 & $3.2 \mathrm{E}+05$ & \\
\hline & Bldg. 3517 & & $1.0 \mathrm{E}+01$ & Sodium carbonate hydrogen & Bldg. $4500 \mathrm{~N}$ & $1.5 \mathrm{E}-01$ & \\
\hline & Bldg. 3525 & & $3.8 \mathrm{E}+01$ & Sodium chloride & Bldg. 7920 & $1.8 \mathrm{E}+05$ & \\
\hline 2,5-dibutylhydroquinone & Bldg. 7920 & $1.1 \mathrm{E}+03$ & & Sodium hydroxide & Bldg. 3092 & 4.7E+06 & \\
\hline 1,4-Diethylbenzene & Bldg. 7920 & & $2.0 \mathrm{E}+02$ & & Bldg. 3544 & $9.7 \mathrm{E}+06$ & \\
\hline Ethanol & Bldg. 3025E & & $4.0 E+00$ & & Bldg. 7900 & $7.0 \mathrm{E}+05$ & \\
\hline 2-ethylhexanol & Bldg. 7920 & & $2.5 \mathrm{E}+01$ & & Bldg. 7920 & $2.0 \mathrm{E}+04$ & \\
\hline Fluoride & Inactive tanks & $7.0 \mathrm{E}+04$ & & Sodium nitrate & Bldg. 7920 & $4.2 \mathrm{E}+05$ & \\
\hline HDEHP extractant & Bldg. 7920 & $5.2 \mathrm{E}+04$ & & Sodium silicate & Bldg $4500 \mathrm{~N}$ & 7.0E-02 & \\
\hline HPLC solvents & Bldg. 4501 & & $8.0 \mathrm{E}+00$ & Sodium thiosulfate & Bldg 7920 & $1.3 E+03$ & \\
\hline Hydrochloric acid & Bldg. $4500 \mathrm{~S}$ & $1.0 \mathrm{E}+01$ & & Strontium & Inactive tanks & $8.9 \mathrm{E}+01$ & \\
\hline Iron & Inactive tanks & $1.7 \mathrm{E}+02$ & & Sulfate & Inactive tanks & $7.2 \mathrm{E}+05$ & \\
\hline Lead & Inactive tanks & $2.4 \mathrm{E}+02$ & & & Bldg. 4501/4505 & $9.0 \mathrm{E}+01$ & \\
\hline Magnesium & Inactive tanks & $2.8 E+03$ & & Sulfuric acid & Bldg. $4500 \mathrm{~S}$ & $1.0 \mathrm{E}+01$ & \\
\hline Magnesium chloride & $4500 \mathrm{~N}$ & $6.0 \mathrm{E}-02$ & & Thallium & Inactive tanks & $4.9 E+02$ & \\
\hline Magnesium sulfate & $4500 \mathrm{~N}$ & $1.4 \mathrm{E}-01$ & & Thorium & Inactive tanks & $7.1 E+03$ & \\
\hline Manganese & Inactive tanks & $6.9 \mathrm{E}+01$ & & Tributyl phosphate & Bldg. 7920 & & $2.0 \mathrm{E}+01$ \\
\hline Mercury & Inactive tanks & $1.3 \mathrm{E}+02$ & & Uranium & Inactive tanks & $6.4 \mathrm{E}+05$ & \\
\hline \multirow[t]{2}{*}{ Methanol } & Bldg. 3025E & & $4.0 \mathrm{E}+00$ & Zinc & Inactive tanks & $1.5 E+02$ & \\
\hline & Bldg. $4500 \mathrm{~N}$ & $1.5 \mathrm{E}+02$ & & Chemical synthesis solutions & Bldg. 4501 & & $8.0 \mathrm{E}+00$ \\
\hline \multirow[t]{2}{*}{ Nickel } & Inactive tanks & $1.6 \mathrm{E}+02$ & & Unknown solvents & Bldg. 4501 & & $4.0 \mathrm{E}+00$ \\
\hline & & & & Total & & $2.4 \mathrm{E}+07$ & $2.4 E+04$ \\
\hline
\end{tabular}




\subsubsection{Characteristics of Future LLLW}

Changes in the radioactivity levels and compositions of LLLW streams during the next 13 years cannot be estimated easily. The following occurrences are expected to have an impact on the radioactivity of the LLLW (the extent of which is given, if known):

1. HFIR conversion of LLLW to solid LLW will remove the majority of ${ }^{3} \mathrm{H},{ }^{24} \mathrm{Na},{ }^{54} \mathrm{Mn},{ }^{60} \mathrm{Co}$, and ${ }^{181,187} \mathrm{~W}$ from the waste. Projections based on current planning scenarios indicate that this conversion will begin in 1998 .

2. The IFDP will generate a significant amount of radioactivity from a broad spectrum of isotopes, including most of those listed in Table 3 (especially ${ }^{90} \mathrm{Sr}$ and ${ }^{137} \mathrm{Cs}$, which would be prominent in the cleanup of Building 3517).

3. REDC source treatment, if implemented, would reduce the activity of its waste stream, especially the TRU content and possibly the ${ }^{137} \mathrm{Cs}$.

Changes in the quantities of nonradioactive contaminants in the LLLW can be summarized as follows:

1. HFIR conversion of LLLW to solid LLW will result in a large decrease in the quantity of $\mathrm{NaNO}_{3}$.

2. The IFDP, when implemented, will result in temporary increases in the quantities of nitric acid, oxalic acid, and cleansing agents (Mr. Clean, Ajax, etc.) used for decontaminating hot cells and glove boxes. Cleanup of the facilities is expected to result in an increase in the isotopic content of the waste. 


\subsection{GENERATION OF LLLW CONCENTRATE}

\subsubsection{Current Generation of LLLWC}

Four waste generators - the inactive tanks, the Process Waste Treatment Plant (PWTP), HFIR, and REDC - are the major sources of LLLWC. Approximately $53 \%$ of the concentrate produced in 1997 is attributed to evaporation of the inactive tank supernates, sluice water, and scabbling water. Regeneration of the ion-exchange columns at the PWTP currently results in an estimated $22 \%$ of the LLLW concentrate. HFIR operations generated an estimated $11 \%$, while REDC generated an estimated $9 \%$ of the total annual LLLWC. These estimates have been based on generator survey information. Table 5 summarizes the concentrate generated during 1993-1997.

LLLWC generation during 1997 is approximately twice that observed during 1996 due to the addition of waste from the Gunite and Associated Tanks (GAAT) in the form of sluice water, supernate, and scabbling water.

\subsubsection{Projected Future Generation of LLLWC}

Table 6 lists the projected LLLWC generation rates for 1998-2010. These rates are calculated, based on the increase or decrease in dilute LLLW generation rates expected and, if known, changes in the concentrations of other contaminants, acids, bases, salts, and cleansers in the LLLW stream. However, in most cases, the current VRFs (calculated on the basis of current LLLW characteristics) are used along with the estimated future dilute LLLW generations to give future LLLWC volumes. These LLLWC volumes are then used to 
Table 5. Generation of liquid low-level waste concentrate for the period 1993-1997

\begin{tabular}{|c|c|c|c|c|c|c|c|c|c|c|}
\hline \multirow[b]{2}{*}{ Generator/facility } & \multicolumn{2}{|c|}{1993} & \multicolumn{2}{|c|}{1994} & \multicolumn{2}{|c|}{1995} & \multicolumn{2}{|c|}{1996} & \multicolumn{2}{|c|}{1997} \\
\hline & (gal/year) & $(\%)$ & (gal/year) & $(\%)$ & (gal/year) & $(\%)$ & (gal/year) & $(\%)$ & (gal/year) & $(\%)$ \\
\hline Process Waste Treatment Plant & 13,800 & 57 & 10,000 & 57 & 9,000 & 53 & 4,400 & 45 & 4,800 & 22 \\
\hline High Flux Isotope Reactor & 7,900 & 32 & 4,500 & 26 & 4,000 & 23 & 2,500 & 26 & 2,500 & 11 \\
\hline $\begin{array}{l}\text { Radiochemical Engineering } \\
\text { Development Center }\end{array}$ & 2,000 & 8 & 1,400 & 8 & 2,500 & 15 & 1,500 & 15 & 2,000 & 9 \\
\hline Bldg. 3517 & 0 & & $<100$ & $<1$ & $<100$ & $<1$ & $<100$ & $<1$ & $<100$ & $<1$ \\
\hline Bldg. 3525 & $<100$ & $<1$ & $<100$ & $<1$ & 100 & $<1$ & 100 & 1 & $<100$ & $<1$ \\
\hline Isotopes Area & $<100$ & $<1$ & 1,000 & 6 & $<100$ & $<1$ & $<100$ & $<1$ & $<100$ & $<1$ \\
\hline Inactive LLLW tanks & $b$ & & $b$ & & $b$ & & 100 & 1 & 11,700 & 53 \\
\hline Others $^{\mathrm{a}}$ & $<550$ & 2 & $<400$ & 2 & 1,500 & 9 & 1,100 & 11 & $<1000$ & 4 \\
\hline TOTAL & 24,450 & & 17,500 & & 17,100 & & 9,800 & & 22,140 & \\
\hline
\end{tabular}

${ }^{a}$ Includes inactive LLLW tank concentrate for 1993-1995. 
Table 6. Projected generation of liquid low-level waste concentrate for the period 1998-2010

\begin{tabular}{|c|c|c|c|c|c|c|c|c|c|c|c|c|c|}
\hline \multirow[b]{2}{*}{ Generalor/facility } & \multicolumn{13}{|c|}{ LLLW concentrate generation (gal/year) } \\
\hline & 1998 & 1999 & 2000 & 2001 & 2002 & 2003 & 2004 & 2005 & 2006 & 2007 & 2008 & 2009 & 2010 \\
\hline Process Waste Treatment Plant & 4,800 & 4,800 & 4,800 & 4,800 & 4,800 & 4,800 & 4,800 & 4,800 & 4,800 & 4,800 & 4,800 & 4,800 & 4,800 \\
\hline High Flux Isotope Resctor & 0 & 0 & 0 & $\mathbf{0}$ & 0 & $\mathbf{0}$ & 0 & 0 & 0 & 0 & $\mathbf{0}$ & 0 & 0 \\
\hline Radiochemical Engineering Dev. Center & 1,700 & 1,700 & 1,700 & 1,700 & 1,700 & 1,700 & 1,700 & 1,700 & 1,700 & 1,700 & 1,700 & 1,700 & 1,700 \\
\hline Spallation Neutron Source Facility & 0 & $\mathbf{0}$ & 0 & $\mathbf{0}$ & 0 & 0 & $<\mathbf{5 0}$ & $<50$ & $<50$ & $<50$ & $<\mathbf{5 0}$ & $<50$ & $<50$ \\
\hline Bldg. 3517 & 3,200 & 3,200 & 3,200 & 0 & 0 & 0 & 0 & $\mathbf{0}$ & 0 & 0 & 0 & $\mathbf{0}$ & 0 \\
\hline Bldg. 3525 & $<100$ & $<100$ & $<100$ & $<100$ & $<100$ & $<100$ & $<100$ & $<100$ & $<100$ & $<100$ & $<100$ & $<100$ & $<100$ \\
\hline Isotopes Area & 3,500 & 3,500 & 2,300 & $<100$ & $<100$ & $<100$ & $<100$ & $<100$ & $<100$ & $<100$ & $<100$ & $<100$ & $<100$ \\
\hline Others & 1,000 & 1,000 & 1,000 & 1,000 & 1,000 & 1,000 & 1,000 & 1,000 & 1,000 & 1,000 & 1,000 & 1,000 & 1,000 \\
\hline Subtotal, generators & 14,200 & 14,200 & 13,000 & 7,500 & 7,500 & 7,500 & 7,500 & 7,500 & 7,500 & $\mathbf{7 , 5 0 0}$ & $\mathbf{7 , 5 0 0}$ & 7,500 & 7,500 \\
\hline Inactive tanks: & & & & & & & & & & & & & \\
\hline Concentrated supernate + sluice water ${ }^{a}$ & 7,300 & 25,800 & 31,900 & 0 & 0 & $\mathbf{0}$ & $\mathbf{0}$ & $\mathbf{0}$ & 0 & 0 & 0 & 0 & 0 \\
\hline Sludge ${ }^{b}$ & 9,800 & 47,000 & 42,000 & 0 & 0 & $\mathbf{0}$ & $\mathbf{0}$ & 0 & 0 & & 0 & $\mathbf{0}$ & 0 \\
\hline EM-40 Programs ${ }^{c}$ & $<100$ & 5,600 & $<100$ & $<100$ & $<100$ & $<100$ & $<100$ & $<100$ & $<100$ & $<100$ & 250 & 400 & 200 \\
\hline Total $^{d}$ & 31,300 & 92,600 & 86,900 & 7,500 & 7,500 & 7,500 & 7,500 & 7,500 & 7,500 & 7,500 & 7,750 & 7,900 & $\mathbf{7 , 7 0 0}$ \\
\hline
\end{tabular}

The volume of concentrate resulting from evapor

c This includes Remedial Action activities and facility D\&D activities.

${ }^{d}$ This total includes all concentrate and sludge added to the MVSTs, with the exception of waste transferred from Bethel Valley tanks (i.e., W-21, -22, -23, and C-1, C-2). 
determine the storage space needed over the next 13 years. The following is a summary of changes that will affect the volume of LLLWC generated over the given time frame:

1. HFIR will dispose of loaded ion-exchange resin as solid waste, eliminating LLLWC from this facility beginning in 1998. The annual volume of solid LLW generated is expected to be approximately $10 \mathrm{~m}^{3}\left(35 \mathrm{ft}^{3}\right)^{7}$

2. After the IFDP has been effectively carried out, Building 3517 will not generate LLLWC.

3. LLLWC generation is expected to vary greatly during the next 3 years, depending on the timing and extent of the remediation of the inactive tanks (liquids and sludges), Surplus Facility Program D\&D projects, and RA activities. Estimates for the volumes of LLLWC to be generated by these programs are given in Table 6 .

4. Waste Management is considering the possibility of combining the PWTP and the Nonradiological Wastewater Treatment Facility. Currently, LLLW results when the ion exchange columns at the PWTP are regenerated. This waste stream would be eliminated if the plants were combined because the ion exchange material utilized in the updated facility would be disposed of as solid waste. This facility modification is being investigated further but has not been finalized nor approved. Therefore, projections in this report assume the current facility configuration and waste generation.

The major activity that will generate significant amounts of LLLWC is sludge removal from the inactive tanks during the next 3 years. The sludge removal and transfer operations are to be performed using process water as a sluicing medium in the case of the eight GAAT. The process water will be used to mobilize and transfer the sludges to the MVSTs, where the 
slurry will be allowed to settle, and the clarified liquid will be returned to BV for evaporation. The tank walls of the GAATs will then be "scabbled," a process in which the walls are etched with high-pressure water to remove a specific amount of the contaminated surface. The scabbling water and resulting material will also be transferred to the MVSTs, settled, decanted, and evaporated.

During 1998, sludge in the five Old Hydrofracture Tanks will be sluiced using the supernate already stored in those tanks and will then be transferred to the MVSTs.

The Bethel Valley Evaporator Service Tanks (ESTs) will also be sluiced and transferred to the MVSTs; however, the sluicing liquid (supernate will be used) and sludge in these tanks (with the exception of tank W-22 sludge) are already accounted for as "stored LLLWC" and, therefore, will not change the total net volume of LLLWC in the system. The sluicing of tank W-22 is expected to add an additional $6800 \mathrm{gal}$ of LLLWC in the form of sludge.

Assumptions were made with regard to the volume of water needed for sluicing a given amount of sludge, the achievable volume reduction for the sluice water, scabbling volumes, etc. These assumptions can be summarized as follows:

1. A maximum of $10 \mathrm{wt} \%$ solids in the slurry is required to transfer sludges to the MVSTs. An estimate of the solids content of the sludge was subtracted from the percentage water reported in the sludges. (This corresponds to a total solids in the wet sludge. $\left.{ }^{8}\right)$ 
2. Scabbling of a gunite tank (170,000 gal) will require 27,000 gal of process water and will generate 600 gal of concrete. ${ }^{9}$ Scabbling of the other tanks was scaled to these assumptions.

3. A VRF value of 20 was assumed for dilute inactive tank supernates and for sluice and scabbling water, based on evaporation ratios achieved to date.

\subsection{STORAGE OF LLLWC}

Several options have been implemented to provide additional storage space in the MVSTs. Several liquid waste solidification projects that were completed during 1988-1995 freed about 191,000 gal of space. Out-of-tank evaporation (OTE) successfully removed 12,600 gal of water from the MVSTs; ITE evaporated 45,000 gal of water from the MVSTs. The reduction of cesium in the supernate at the MVSTs was successfully demonstrated during 1997 using a crystalline silicotitanate ion exchanger.

According to the current strategy plans, six new 100,000-gal storage tanks will be available in 1998 - thus increasing the Operational Safety Report (OSR) limit to 900,000 gal. The OSR limit is calculated by (1) allowing tank W-21 to serve as an LLLW feed tank;

(2) permitting tank W-23 to be used for segregation of waste only, not storage; and

(3) decreasing the maximum tank capacity to $90 \%$ rather than the current $95 \%$. The OSR also requires that the equivalent volume of one tank remain available for emergency use.

Very large quantities of LLLWC are predicted to be generated in the next several years, mainly due to the movement of inactive tank waste to the active system. This transfer of 
waste, which is set to occur on a very tight schedule, will consolidate all of the LLLW and transuranic sludges in the MVSTs in preparation for removal/treatment and disposal by an outside contractor. Fulfillment of this schedule hinges primarily on the availability of the new CITs. A change in their operational date will affect the schedule for transfer of the inactive tank waste and, in turn, generation of the LLLWC over the next several years.

\section{SUMMARY AND CONCLUSIONS}

Generation rates for dilute LLLW at ORNL are somewhat higher for CY 1997, primarily because of the transfer of 153,000 gal of supernate waste from inactive tanks. The volume reduction of this waste has not been as high as expected, and the resulting volume of concentrate was much higher, with a total volume of concentrate for the year approximately double that of the last several years. Most other generators have not significantly changed their 1997 waste generation rates over the previous year's estimates. Groundwater and rainwater continue to make up a large portion (approximately 30\%) of the dilute LLLW generation for 1997. All other facilities have predicted generation rates comparable with the previous year's generations. 


\section{REFERENCES}

1. L. E. McNeese, J. B. Berry, G. E. Butterworth III, E. D. Collins, T. H. Monk, B. D. Patton, and J. W. Snider, Overall Strategy and Program Plan for Management of Radioactively Contaminated Liquid Wastes and Transuranic Sludges at the Oak Ridge National Laboratory, ORNL/TM-10757, December 1988.

2. T. J. Abraham, S. M. DePaoli, A. B. Walker, and S. M. Robinson, Preliminary Analysis of the ORNL LLLW System, ORNL/TM-11250, August 1994.

3. S. M. DePaoli, Liquid Low-Level Waste Generation Projections for ORNL in 1993, ORNL/TM-12638, April 1994.

4. S. M. DePaoli and G. D. West, Projections for Liquid Low-Level Waste at ORNL in 1995, ORNL/TM-13131, December 1995.

5. Energy Systems Environmental Restoration Program, Work Plan for the Isotopes Facilities Deactivation Project at Oak Ridge National Laboratory, September 1994.

6. J. R. Devore, Oak Ridge National Laboratory, personal communication, 1997.

7. Waste Management and Remedial Action Division, ORNL Waste Management Plan Fiscal Year 1994, ORNL/TM-11433/R3, December 1993.

8. J. M. Keller, J. M. Giaquinto, and W. H. Griest, Characterization of Selected Waste Tanks from the Active LLLW System, ORNL/TM-13248, August 1996.

9. B. E. Lewis, Oak Ridge National Laboratory, personal communication, 1997. 


\section{INTERNAL DISTRIBUTION}

$\begin{array}{rlll}\text { 1. } & \text { J. B. Berry } & \text { 20. } & \text { J. J. Maddox } \\ \text { 2. } & \text { J. A. Chapman } & \text { 21. } & \text { L. E. McNeese } \\ \text { 3. } & \text { E. D. Collins } & \text { 22. } & \text { D. R. McTaggart } \\ \text { 4. } & \text { D. G. Cope } & \text { 23. } & \text { S. R. Michaud } \\ \text { 5. } & \text { A. G. Croff } & \text { 24. } & \text { T. H. Monk } \\ \text { 6. } & \text { D. L. Daugherty } & \text { 25. } & \text { T. E. Myrick } \\ \text {-11. } & \text { S. M. DePaoli } & \text { 26. } & \text { B. D. Oakley } \\ \text { 12. } & \text { J. T. Etheridge } & \text { 27. } & \text { D. J. Peterson } \\ \text { 13. } & \text { D. D. Foust } & \text { 28. } & \text { J. H. Platfoot } \\ \text { 14. } & \text { J. R. Forgy } & \text { 29. } & \text { S. M. Robinson } \\ \text { 15. } & \text { L. L. Kaiser } & \text { 30. } & \text { S. T. Rudell } \\ \text { 16. } & \text { C. M. Kendrick } & \text { 31. } & \text { T. F. Scanlan } \\ \text { 17. } & \text { T. E. Kent } & \text { 32. } & \text { C. B. Scott } \\ \text { 18. } & \text { P. S. Kirkham } & \text { 33. } & \text { R. B. Shelton } \\ \text { 19. } & \text { J. M. Lynch } & \text { 34. } & \text { R. C. Stewart }\end{array}$

35. L. E. Stratton

36. P. A. Taylor

37. J. R. Trabalka

38. M. W. Tull

39. S. D. Van Hoesen

40-44. A. B. Walker

45. J. F. Walker, Jr.

46. M. L. Whitehead

47. Central Research Library 48-49. Laboratory Records- $\mathrm{RC}$ 50-51. Laboratory Records (for OSTI)

52. WMRAD Document Management Center

\section{EXTERNAL DISTRIBUTION}

53. S. Gibson, USDOE, 55 Jefferson, EW 92 , Oak Ridge, TN 37830

54. C. Mims, USDOE, 55 Jefferson, EW92, Oak Ridge, TN 37830

55. J. Noble-Dial, USDOE, 55 Jefferson, EW92, Oak Ridge, TN 37830

56. J. Powell, USDOE, 55 Jefferson, EW92, Oak Ridge, TN 37830

57. G. Riner, USDOE, 55 Jefferson, EW92, Oak Ridge, TN 37830 


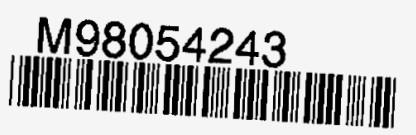

Report Number (14) ORNL/TM $--135 / 3$

Publ. Date (11) $\frac{199803}{\text { DOE/EM }, ~ X F}$
Sponsor Code (18)
UC Category (19) $U$ UC-2000, DOE/ER 